\title{
Addictions in Spanish College Students in Confinement Times: Preventive and Social Perspective
}

\author{
Cristina Lázaro-Pérez ${ }^{1}$, José Ángel Martínez-López ${ }^{2}$ (1) and José Gómez-Galán ${ }^{3,4, *(\mathbb{D})}$ \\ 1 Department of Sociology, University of Murcia, Campus Universitario, 11, 30100 Murcia, Spain; \\ cristina.lazaro2@um.es \\ 2 Department of Social Work and Social Services, University of Murcia, Avda. Teniente Flomesta, 5, \\ 30003 Murcia, Spain; jaml@um.es \\ 3 Department of Education, University of Extremadura, Avda. de Elvas, s/n, 06006 Badajoz, Spain \\ 4 College of Education, Ana G. Méndez University, Cupey Campus, San Juan, PR 00926, USA \\ * Correspondence: jgomez@uagm.edu
}

Received: 1 October 2020; Accepted: 24 October 2020; Published: 31 October 2020

\begin{abstract}
Diverse studies have shown that a significant percentage of the Spanish university population suffers from different addictions. They are both a personal and public health problem if there is not a greater awareness of the risks involved and if the appropriate prevention measures are not taken, among them educational ones. In this context, a descriptive and explanatory cross-sectional study was conducted during the first half of June 2020, coinciding with the period of confinement that occurred in Spain during the first wave of the COVID-19 pandemic. Given that this is such an exceptional time, the main objective of this study was to obtain information especially on students' substance consumption and possible addictions at this time. Knowing the specific situation of this problem in that specific situation may allow for comparative studies in the future. The sample was composed of 310 university students from 14 Spanish universities. The instrument used in the research was the ASSIST questionnaire, developed by the WHO for the detection of alcohol, tobacco, and substance consumption. As result, a moderate and high risk was observed mainly in the following substances: alcohol $(36.2 \%)$, tobacco $(33.2 \%)$, cannabis $(22.9 \%)$, and sedatives $(10.3 \%)$. Through the logistic regression of the set of drugs, it has been proven that, on the one hand, the addiction to cocaine and sedatives in the family environment and age, on the other hand, are the main predictive variables of drug consumption. The existence of polysubstance abuse was also determined. These data show the need for educational bodies and university institutions to promote awareness, sensitization, and health education programs to deal with this important problem, especially in extraordinary situations, such as the one referred to, which could increase this consumption.
\end{abstract}

Keywords: addictions; health education; prevention; college students; addictive disorders; higher education; confinement; COVID-19

\section{Introduction}

The COVID-19 pandemic presents great challenges for humanity and especially for the most vulnerable populations (Douglas et al. 2020; Lancet 2020; Mesa et al. 2020). For example, the poor (Anser et al. 2020), the elderly (Garnier-Crussard et al. 2020; Morley and Vellas 2020) and the disabled (Thelwall and Levitt 2020; Boyle et al. 2020; Schiariti 2020), those who are ill or who have habits that are harmful to their health, both because of the infection and its associated complications and because they cannot receive individualized care (Armitage and Nellums 2020). 
Certain psychological, psychiatric, and behavioral conditions in mental health require specific attention, especially in serious situations such as those experienced during the first half of 2020 (Holmes et al. 2020; Pfefferbaum and North 2020; Yao et al. 2020; Di Gennaro et al. 2020; Duan and Zhu 2020). The period of home confinement and the consequent precariousness and exclusion to which part of the population is subjected has led to a situation of alarm not only physically but also psychologically and socially (Xie et al. 2020; Santos 2020; Gómez-Salgado et al. 2020; Vicario-Merino and Muñoz-Agustín 2020; Volkow 2020). This scenario has been reinforced by the economic and labor losses, break-ups, or deaths of loved ones without the possibility of a farewell, whose consequences are psychological distress, anxiety, and depressive symptoms (Liu et al. 2020). In this context, eating disorders, post-traumatic stress, psychotic disorders, depressions, and addictions (alcohol, substance abuse, and non-substance abuse) are emerging (Cruces-Montes et al. 2020; OME-OSALDE 2020).

Previous studies show the relationship between isolation and quarantine situations such as the one derived from the context of COVID-19 and disorders such as anxiety, stress, and drug use (Gage and Sumnall 2018; Bloem et al. 2019), as a way of dealing with fear, uncertainty, and isolation (Doyle et al. 2019). This context can generate psychological consequences and through consumption, subjects adapt to the overwhelming situation (Taylor 2019). These contextual factors may be the triggers for the initiation of substance use, (Rojas-Jara 2020) with drug use being both an avoidant behavior (Brunner et al. 2019) and a pleasurable one (Filbey 2019).

Regarding addictions, substance use can lead to dependence through abuse or intoxication. This behavior not only has repercussions for those who use it, but also influences the people with whom it is lived or related, that is, consequences at the family, social, and community levels (Duan and Zhu 2020). How these emerging emotions are managed depends, in part, on the type of relationship that is maintained with the rest of the people with whom one lives during this long period of isolation.

The consumption of drugs by young people in Spain because of the socialization of these drugs sets different standards concerning other countries in the world. Their consumption habits are different and are linked to cultural elements, access to drugs, and permissive legal norms. However, there are also some common aspects linked to this stage of life (Panchal et al. 2020; Romo-Avilés et al. 2016a). Social and relational factors are important in the initiation of drug use, but family variables (Romo-Avilés et al. 2016b; Moore et al. 2010) acquire a differential value by favoring access to drugs, especially alcohol and tobacco.

However, not only family and social variables can be determinants of substance use among university students, but also personal variables, since the university is a place of high anxiety (Böckerman et al. 2017). Additionally, student perfectionism in its broadest sense is a factor that can trigger high levels of anxiety and depression, and thus lead to psychological problems (eating disorders, sadness, feelings of abandonment, etc.), as well as increase the consumption of drugs. Recent studies (Luquiens et al. 2016; Egan et al. 2011) show the relationship between these components: levels of perfectionism and psychological disorders in school children, which can be extrapolated to higher academic studies.

Drug use in early adulthood has not been studied as much as other stages of the life cycle, but it is beginning to arouse the interest of some researchers (Tafà et al. 2017; Parolin et al. 2017). In Spain, numerous studies address access to and use of drugs by the young student population, although some approaches have been made to young university students in recent years (Melero et al. 2020; Moure-Rodríguez et al. 2016). The ESTUDES survey conducted by the Ministry of Health in Spain on drug use specifically excludes young university students (Mota et al. 2010).

Recent studies show that drug use in young people does not necessarily have to become a generalized problem from a clinical perspective, since family, environmental, and personal variables can be predictive (Observatorio Español de las Drogas y las Adicciones 2019). University students are not far from these realities and their personal, family, and social difficulties can lead to an increase in their vulnerability to drug use, issue must be taken into account due to the worrying consequences that frequent consumption can have, such as the development of disorders such as psychosis (Van der Steur 
et al. 2020), memory performance deficits (Blest-Hopley et al. 2020), depression (Gonzálvez et al. 2020), sleep disturbance, anxiety (Winhusen et al. 2019), among others.

\section{Background}

Sporadic use of an illegal substance is not considered an addiction. A designation of addiction should meet at least two of the diagnostic criteria listed in the Diagnostic and Statistical Manual of Mental Disorders (DSM) of the American Psychiatric Association (American Psychiatric Association 2013) for 12 months: dangerous use, social or interpersonal conflicts linked to the use, omission of the main roles due to the use, abstinence syndrome, tolerance; that is, increased or longer use of the substance, continued attempts to stop or control the use, investment of more time than planned in activities related to the use, physical or psychological problems related to the use, stopping other activities due to the use. There is a circuit of natural enhancers that is common to different types of addictions, such as gambling addiction (gambling), internet use, sports, sex, etc. (Becoña and Cortés 2011).

Transdiagnostic theories suggest that addictions, even behavioral ones, should be conceptualized by their similarities rather than their differences, not as distinct and unique disorders, but symbolizing a common underlying conflict with unique manifestations such as alcohol, cannabis, gambling, or video games (Kim et al. 2020). The latest editions of DSM-5 and the World Health Organization's International Classification of Diseases (ICD-11) have recognized the similarities between different addiction disorders (World Health Organization (WHO)).

According to recent studies, young people who have a higher prevalence of alcohol, tobacco, and cannabis use are those who believe they are well informed and think that certain use situations cause few problems (Belzunegui-Eraso et al. 2020). Therefore, drug use in Spain is not related to the absence of drug education, nor is there evidence that educational level reduces drug use, especially in the university setting (Melero et al. 2020; Moure-Rodríguez et al. 2016; Caamaño-Isorna et al. 2008). On the other hand, according to previous studies and taking into account the psychopathological aspect, patients with Heroin Use Disorder were younger than those suffering from major depression (Maremmani et al. 2015).

Although alcohol use usually begins at an early age such as adolescence, alcohol use disorder often occurs later, in the 20s and 30s (Liu et al. 2020). Numerous studies (Böckerman et al. 2017; Egan et al. 2011; Quaglieri et al. 2020; Vargas-Martínez et al. 2020; Song et al. 2012; Jander et al. 2013) show how alcohol is a very dangerous drug because of its relationship with the initiation of other drugs, as well as social acceptance of it, with the risk of high consumption influenced by family attitudes (Duan and Zhu 2020; Melero et al. 2020) and peer group relationships.

In Spain, as in other Mediterranean countries, alcohol consumption, and the patterns associated with it is one of the characteristic features of our country (Bosque-Prous et al. 2017). Besides, alcohol is related to consumption patterns of other drugs. Alcohol use predicts subsequent cocaine use, and cocaine use predicts cannabis use, which in turn increases the likelihood of cocaine use. Thus, alcohol, as a culturally and socially accepted drug, is the gateway to another drug use (Rolando et al. 2014). Concerning gender, the greater equalization of the gender gap in alcohol consumption in the young population is a result of the increased consumption of alcohol by females (Panchal et al. 2020; Romo-Avilés et al. 2016a; Mota et al. 2010; Gervilla and Pol 2009; Bartsch et al. 2017; Díaz Geada et al. 2018).

According to the ICD-11, smoking, as a substance use disorder, is considered a mental and behavioral illness. Smoking is also categorized as a substance use disorder, similar to alcohol, cannabis, etc. In a specific study on smoking in the medical population, they found that greater dependence on nicotine among physicians was associated with an earlier age of smoking initiation, thus evidencing the need to support the development of strategies to postpone smoking initiation (Moure-Rodríguez et al. 2016; Põld and Pärna 2020; BOE 2005). As with alcohol, tobacco consumption is a socially accepted drug, although since the approval of Law 28/2005, December 26, measures have been introduced against smoking and regulating the sale, supply, consumption, and advertising of 
tobacco products (Villalbí et al. 2012). Although use of the drug begins in adolescents at an early age, recent years have seen a reduction in its use by this age group (Eurostat 2020).

Data from Europe show that between the ages of 25 and 64, the average prevalence of daily smoking in 2014-the last year for which data are available-was $27.8 \%$ for men and $19.8 \%$ for women (Perelman et al. 2019). A recent study (Brunetti et al. 2020) highlights the relationship between excessive smoking and school absenteeism among young people. In Spain, among the university population, the result in regular smoking was $20.6 \%$ - the third most prevalent country-and $2.9 \%$ in occasional smoking — the second least prevalent. By gender, men showed $21.3 \%$ - the seventh with the highest prevalence in daily smokers-and 3.1\% in occasional smokers-the second with the lowest prevalence. Women, however, accounted for $20.0 \%$ (third most prevalent among daily smokers) and $2.8 \%$ among occasional smokers (third least prevalent) (Perelman et al. 2019).

Regarding cannabis, it has been used for centuries for therapeutic purposes to treat neuralgia, seizures, migraines, rheumatic pain, constipation, sexual disorders, asthma, malaria, insomnia, or gout (European Monitoring Center for Drugs and Drug Addiction (EMCDDA)). However, precisely because of the abuse of its consumption outside of medical applications, its therapeutic use began to decrease. In 1961, cannabis was included in the Single Convention on Narcotic Drugs of the United Nations (United Nations 1961), and the use, possession, production, manufacture, export, import, distribution, and trade of cannabis and other drugs were prohibited, except for medical and scientific purposes (World Health Organization 2016).

Cannabis is now the second most widely used substance in the world, after alcohol (Greaves and Hemsing 2020), and its widespread use globally reveals that developing evidence of its effects is already a critical global health problem, so actively monitoring trends in recreational cannabis use, especially where it has been legalized, is critical to understanding its implications (San Martín 2020). Recent research associates cannabis use with family and educational variables. A French study found that regular cannabis use was associated with lower family socio-economic status and school failure, while adolescents from affluent families tended to use it occasionally (Legleye et al. 2012).

Regarding cocaine, recent research (Gerra et al. 2020) shows that experimental and episodic use is significantly associated with low family socioeconomic status, but not with frequent use. Low parental education is significantly associated with experimental and frequent use, but not with episodic use. Whereas, school absenteeism is significantly associated with all three types of cocaine use: experimental, episodic, and frequent.

According to the Observatorio Español de las Drogas (Spanish Drug Observatory) (Observatorio Español sobre Drogas 2019), in 2017 the drugs with the highest prevalence in the Spanish population aged 15-64 years (during the year before the study) were alcohol, tobacco, and hypo-sedatives. Cannabis and cocaine use are more distant. Tobacco and alcohol are preferentially consumed at younger ages, followed by cannabis. In contrast, in the later ages, the increase of sedatives stands out.

The Survey on Drug Use in Secondary Education in Spain (ESTUDES) (Mota et al. 2010) shows that among 14- to 18-year-olds, alcohol is the most widely consumed psychoactive substance in Spain. In figures, $77.9 \%$ of these young persons had consumed alcoholic beverages at some time in their lives; $75.9 \%$ had consumed alcohol in the last year and 58.5\% admitted to having drunk alcohol during the last month before the study. In 2019, 81.3\% of the Spanish population aged 15 to 64 years old consumed alcohol in the last year, choosing wine as a second option over other alcoholic beverages (Cruces-Montes et al. 2020), a symbol of how deeply rooted this drink is in Spanish culture.

Alcohol is followed by tobacco. The third most commonly used drug among 14-18-year-olds is cannabis. The fourth most prevalent substance is hypo-sedatives (tranquilizers/insomniacs) with or without a prescription.

Cocaine prevalence was less than 3\% among regular users (Mota et al. 2010). In short, except for cocaine which experienced a decline in use, all other substances showed an upward trend in use over previous years. 
Sedatives are evolving rapidly and their consumption is increasing dramatically. One of the few studies on drugs conducted among 16-24 year-olds, which included university students, showed that self-medication was generally $20.75 \%$, reaching $23.27 \%$, in university students (Pedersen and Soest 2013). The occasional intake, frequency, and intoxication of these drugs underscore the need for further research. The increase in recreational drug intoxication in the emergency department in the context of multiple-use is noteworthy, making access, use, and abuse (mainly benzodiazepines) a public health risk and a problem that highlights the need for control of their distribution (Puiguriguer-Ferrando et al. 2019).

While it is true that during the period of confinement in Spain resulting from the Declaration of State of Alarm, which involved full confinement of the population, difficulty in purchase or fear of contagion could lead to a decrease in consumption of certain substances, it is also possible that the circumstances surrounding confinement such as the confinement itself, anxiety, or other psychological issues could activate consumption and relapses, especially in people whose treatment had to be interrupted. Various studies have shown that endogenous stress is responsible for the phenomenon of craving during the withdrawal phase (Pedrero-Perez et al. 2008).

Recent studies have shown the relationship between the intake of certain substances and the implications of COVID-19 for patients. For example, since COVID-19 causes a severe lung infection, it may increase the risk of respiratory dysfunction among opioid users (Observatorio Europeo de Drogas y Toxicomanías 2020). Regarding patients infected with COVID-19 and the severity of the disease in smokers, (Vardavas and Nikitara 2020) they found that one in three cases with respiratory complications was somehow related to tobacco use since it weakens the immune system.

Concerning hypo-sedatives drugs, this pandemic has shown how certain drugs such as antipsychotics and antidepressants, opioid analgesics, anticholinergics, or inhaled corticosteroids can increase the risk of pneumonia by 1.2 to 2.7 times by depressing the immune and protective systems (Laporte and Healy 2020). These are not the only effects, as stimulants such as cocaine can trigger a high incidence of cardiovascular disease, especially among patients who inject drugs and use cocaine (Thylstrup et al. 2015), making their condition worse or impairing their recovery when they contract COVID-19. Thus, confinement may have activated mechanisms that can lead people who already had habits of consumption of acquired illegal substances to resume them or in certain cases to enhance or initiate them.

Making provisions regarding drug use in young people and the variables that trigger it is essential to provide the necessary means to help avoid maladaptive and self-injurious behavior. The characteristics of drug use in the university population may be different and drug use may become both a personal and a public health problem. This is the case especially if it becomes a repetitive and ingrained behavior in these young people (Observatorio Español de las Drogas y las Adicciones 2019). Therefore, it is necessary to approach the consumption of these drugs in this group, taking into account both internal and external variables.

\section{Materials and Methods}

\subsection{Objectives}

Toxic consumption among the young population is increasing in Spain. This situation is aggravated by the socialization of alcohol and tobacco consumption, starting with drug addictions at a very early age. Now, moreover, something exceptional has happened, such as the COVID-19 health crisis. As this is such an extraordinary time, therefore, the main objective that is determining for us is to obtain information about the consumption of substances and possible addictions of students at this time. This would allow us to know more about the situation during confinement, as well as being able to serve as a basis for comparative studies in the future. 
Therefore, the main objective (PO) that we pursue is to present information on the situation, in terms of substance consumption, of Spanish university students during the first wave of the COVID-19 pandemic, in the context of the State of Alarm decreed in Spain.

Depending on this main objective, two secondary objectives are pursued, always within the scope of determining the consumption of each toxic substance. The first secondary objective (SO1) is to statistically establish what type of young university students consume drugs and whether there is polysubstance use (addiction to 2 or more drugs) in their profiles. The second secondary objective (SO2) aims to find out if there are predictive variables in drug consumption and to identify what its components would be. This would be of great interest to establish profiles of student users, or potential users so that university institutions can apply strategies to reduce these addictions. In this context, it should be noted that drug consumption by certain university students may be conditioned mainly by the family context, reproducing their consumption patterns, without sociodemographic aspects being a determining factor. All this information must be known.

In any case, this would be additional information to what we are pursuing, such as establishing a description of the situation of Spanish university students about consumption and possible addictions to substances in times of this confinement. We would like to say that we are at a decisive moment and that this data can be very valuable, above all when thinking about the future, it is very useful for comparative studies that can determine an evolution.

\subsection{Study Design and Sample}

The cross-sectional descriptive and exploratory study was carried out in the first half of June 2020. The protocol followed all the guidelines of the Ethics Committee of the universities to which the members of the research team belong. For the fieldwork carried out in Spain, the official approval of the universities is not necessary if it is a question of descriptive studies, as it has been carried out (it is only required in the experimental ones). However, the Codes of Good Practice for Research on Human Beings, which are collected by the Ethics Committees, were signed and the study was registered (code No. REPRIN-PEM-04) by the research team that was made up of the authors.

All participants $(\mathrm{N}=310)$ gave their informed consent following the Declaration of Helsinki. The instrument used to collect the information, in the form of a confidential anonymous online questionnaire, was transmitted through a tool used by the University of Murcia based on a telematics data collection system. It uses advanced software that allows the design of totally personalized surveys that can be adapted to any device (responsive system). The participants had to accept the ethical conditions and give their consent before accessing the questionnaire and sending their answers.

Due to the special circumstances of confinement and the urgency of obtaining the information, the sample carried out was of convenience, being applied to groups of students of which the researchers are professors, as well as students of colleagues from other Spanish universities who obtained prior permission from their students to participate in the study. In this way, a sample was obtained from a group of 14 universities in Spain and a total of 310 students.

The instrument used in the research was an ASSIST questionnaire, developed by the WHO for the detection of alcohol, tobacco, and substance use (WHO 2010). The questionnaire consists of eight questions on addiction to the following toxic substances: tobacco, alcohol, cannabis, cocaine, amphetamine-type stimulants, inhalants, sedatives or sleeping pills, hallucinogens, opiates, and other drugs.

The time interval that the ASSIST questionnaire analyses to identify the level of drug consumption refers to the previous 3 months. Therefore, the results of this study are framed within the most virulent period of the SARS-CoV-2 health crisis, framed by the confinement of the Spanish population where social contact was highly restricted.

Another reason for using the ASSIST questionnaire is the absence of cultural bias, which could allow comparison of results with research in other countries. Taking this instrument as a reference, 
questions related to socio-demographic and family variables were included. The final questionnaire consisted of 21 questions.

The declaration of the State of Alarm decreed in Spain because of the COVID-19 health crisis meant that it was impossible to carry out the questionnaire in person, so it was distributed virtually through a platform designed for carrying out surveys. This strategy made it possible to increase levels of sincerity by avoiding the possible bias of feeling judged by whoever had administered the questionnaire.

\subsection{Variables Used}

A. Dependent variable. The ASSIST questionnaire allows the identification of the consumption risk of each subject according to three levels: low, moderate, and high. In the descriptive analysis, this classification has been maintained, but in the subsequent statistical analysis, the variable of the risk of consumption of each of the toxic substances was re-codified, establishing it as low or moderate/high. This decision is justified for several reasons. Firstly, the interpretation of the ASSIST questionnaire (WHO 2010) indicates that moderate consumption shows the presence of some health and other problems (economic, legal, family, etc.) On the other hand, consumption at these levels may indicate a probable future dependency (54). Therefore, the dependent variable of this research is the risk of moderate/high consumption in each of the drugs considered: tobacco, alcohol, cannabis, cocaine, amphetamine-type stimulants, inhalants, sedatives or sleeping pills, hallucinogens, opiates, and other drugs.

B. Independent variables. The independent variables were grouped into two different categories: socio-demographic and family. Concerning the sociodemographic variables, the following were established: (a) gender (male/female), (b) age (18-21 years, 21-24 years, and >24 years), (c) branch of knowledge of their degree (Art and Humanities, Sciences, Health Sciences, Social and Legal Sciences, and Engineering and Architecture), and (d) whether they had ever consumed the different toxic substances included in the questionnaire.

Regarding the family variables, the following were included: (a) maximum level of education of the mother, (b) maximum level of education of the father, (c) relationship with the labor market of the mother, (d) relationship with the labor market of the father, (e) mental illness of one of the family members, and (f) consumption in his family environment of the following substances: tobacco, alcohol, cannabis, cocaine, amphetamine-type stimulants, inhalants, sedatives or sleeping pills, hallucinogens, opiates, other drugs, social networks, or video games. Regarding the variables related to the highest level of education, three categories were established: low (up to formal compulsory education), medium (above compulsory education but below university), and high (university education). Regarding the relationship with the labor market, the following categories were established: employed and unemployed/inactive. Finally, regarding substance addictions in the family environment, it was decided to not consider only the social origin (father/mother) but the influence that any member of the family nucleus can have.

\subsection{Statistical Analysis}

The procedure was structured in three phases. Firstly, a descriptive analysis was carried out through frequency analysis. Subsequently, a cross-table analysis was performed to establish the relationship between the dependent variable (moderate/high risk of consumption of each of the drugs) and the independent ones (sociodemographic and family) according to their chi-square significance level $(p<0.005)$. Finally, a binary logistic regression was performed for each of the drugs to check the predictive variables in their consumption (see Appendix A). In this technique, age was established as a continuous variable and not as a discrete one as it was done in the frequency and cross-table analysis.

In the binary logistic regression, the forward model was used, which automatically re-evaluates the coefficients and their significance, eliminating from the model those variables that are not statistically significant (Berlanga-Silvente and Vila-Baños 2014). 


\section{Results}

The descriptive analysis shows the following results (Table 1). First, concerning the sociodemographic variables, $69.9 \%$ were women and $30.1 \%$ men. One of the reasons for this overrepresentation is the greater number of women in Spanish universities compared to men (Ministerio de Ciencia and Innovación y Universidades 2019). The average age was 23.7 years. If a distribution by age is made, the highest number is concentrated among those aged 21-24 years (46.1\%), followed by those entre 18-21 years (31.3\%) and finally, those over 24 years (22.6\%). Regarding the branch of knowledge of their degree, worth noting was Social and Legal Sciences, which applied to $47.5 \%$ of the participants.

Regarding the family variables, for the majority of respondents, both parents had basic academic training: $46.7 \%$ in the studies of the mother and $52.0 \%$ in both parents. Regarding the work of the parents, a higher level of employability was observed in their fathers (72.2\%) than in their mothers $(53.3 \%)$, under the higher level of occupation of men in the labor market (INE 2020).

Table 1. Descriptive analysis of the variables.

\begin{tabular}{|c|c|c|c|c|c|}
\hline \multicolumn{6}{|c|}{ Students Features } \\
\hline Gender & Woman & Man & & & \\
\hline & 69.9 & 30.1 & & & \\
\hline Age & $18-21$ & $21-24$ & $>24$ & & \\
\hline & 31.3 & 46.1 & 22.6 & & \\
\hline Knowledge Branch & $\begin{array}{c}\text { Arts and } \\
\text { Humanities }\end{array}$ & Sciences & $\begin{array}{l}\text { Health } \\
\text { Sciences }\end{array}$ & $\begin{array}{c}\text { Social and } \\
\text { Legal Sciences }\end{array}$ & $\begin{array}{l}\text { Engineering } \\
\text { and } \\
\text { Architecture }\end{array}$ \\
\hline & 16.4 & 12.1 & 18.0 & 47.5 & 5.9 \\
\hline Ever Consumed: & Yes & No & & & \\
\hline Tobacco & 65.2 & 34.8 & & & \\
\hline Alcohol & 90.6 & 9.4 & & & \\
\hline Cannabis & 59.0 & 41.0 & & & \\
\hline Cocaine & 10.3 & 89.7 & & & \\
\hline Stimulants & 12.6 & 87.4 & & & \\
\hline Inhalants & 9.7 & 90.3 & & & \\
\hline Sedatives & 22.9 & 77.1 & & & \\
\hline Hallucinogens & 12.9 & 87.1 & & & \\
\hline Opiates & 5.5 & 94.5 & & & \\
\hline Others & 17.4 & 82.6 & & & \\
\hline Polysubstance Use & 30.3 & 69.7 & & & \\
\hline Consumption Risk & Low & Moderate & High & & \\
\hline Tobacco & 66.8 & 31.3 & 1.9 & & \\
\hline Alcohol & 63.9 & 26.8 & 9.4 & & \\
\hline Cannabis & 77.1 & 22.6 & 0.3 & & \\
\hline Cocaine & 95.2 & 4.8 & 0 & & \\
\hline Stimulants & 96.1 & 3.9 & 0 & & \\
\hline Inhalants & 97.4 & 2.6 & 0 & & \\
\hline
\end{tabular}


Table 1. Cont.

\begin{tabular}{|c|c|c|c|}
\hline \multicolumn{4}{|c|}{ Students Features } \\
\hline Sedatives & 89.7 & 9 & 1.3 \\
\hline Hallucinogens & 95.5 & 4.5 & 0 \\
\hline Opiates & 97.7 & 2.3 & 0 \\
\hline Others & 97.4 & 2.6 & 0 \\
\hline \multicolumn{4}{|l|}{ Family Features } \\
\hline \multirow[t]{2}{*}{ Mother's Education } & Basic & Medium & Advanced \\
\hline & 46.7 & 26.6 & 35.6 \\
\hline \multirow[t]{2}{*}{ Father's Education } & Basic & Medium & Advanced \\
\hline & 52.0 & 23.2 & 24.9 \\
\hline \multirow[t]{2}{*}{ Mother's Profession } & Employed & \multicolumn{2}{|c|}{ Unemployed/Inactive } \\
\hline & 53.3 & 5.2 & \\
\hline \multirow[t]{2}{*}{ Father's Profession } & Employed & Unemploye & nactive \\
\hline & 72.2 & 27.8 & \\
\hline $\begin{array}{l}\text { Other Problems or } \\
\text { Addictions }\end{array}$ & Yes & No & \\
\hline Mental Disease & 19.9 & 80.1 & \\
\hline Tobacco Addiction & 38.7 & 61.3 & \\
\hline Alcohol Addiction & 13.0 & 87.0 & \\
\hline Cannabis Addiction & 8.2 & 91.8 & \\
\hline Cocaine Addiction & 3.0 & 97.0 & \\
\hline Addiction Stimulants & 0.7 & 99.3 & \\
\hline Addiction Sedatives & 8.5 & 91.5 & \\
\hline $\begin{array}{l}\text { Addiction Social } \\
\text { Networks }\end{array}$ & 21.6 & 78.4 & \\
\hline $\begin{array}{l}\text { Video Game } \\
\text { Addiction }\end{array}$ & 16.6 & 83.4 & \\
\hline
\end{tabular}

An approximation of the level of consumption of university students shows that four drugs stand out that they admit to having taken at some time: alcohol (90.6\%), tobacco $(65.2 \%)$, cannabis (59.0\%), and over-the-counter sedatives (22.9\%). These data show that: (a) the socialization of alcohol and tobacco exists in young university students; (b) cannabis exhibits similar levels to tobacco, which makes it evident that university students are close to this drug; and (c) the percentage of sedative use within the general context of drug consumption reflects the self-diagnosis and self-medication of young university students and, in general, the medicalization of developed societies (Iriart and Merhy 2017; Martínez-Gayo and Martínez-López 2020; Martínez-López and Martínez-Gayo 2019).

Going deeper into the risk of consumption according to the ASSIST scale, it can be seen that most students have low consumption of these drugs. Only moderate and high risk is observed mainly in the substances indicated above: alcohol $(36.2 \%)$, tobacco $(33.2 \%)$, cannabis $(22.9 \%)$, and sedatives $(10.3 \%)$. The most relevant of these data is that a third of university students have a moderate or high risk of alcohol and tobacco consumption, being in the specific case of alcohol at a high risk of 9.4\%. Moreover, it should be noted about the main consequences of alcohol consumption that high consumption indicates that the subject may have health, social, economic, legal, and personal relationship problems (Põld and Pärna 2020). It is also striking that the risk of moderate/high consumption of cannabis is very high, with nearly 1 in 4 people showing this addiction. Regarding the use of sedatives, the use of which 
will need to be carefully analyzed in future research, it may be closely related to the health context arising from COVID-19 and confinement, which affected society as a whole by increasing stress and anxiety (Marsden et al. 2020; Brown et al. 2020; Rajkumar 2020). Finally, cocaine consumption reached $4.8 \%$ and that of hallucinogens reached $4.5 \%$ at moderate risk. About polydrug use (consumption of two or more substances), $30.3 \%$ of university students showed this level of addiction, that is, almost 1 in 3 , revealing data on the level of addiction in these young people.

In the final part of the table, the results of the family characteristics (mental illness and drug addiction) are shown with a percentage $\geq 3 \%$. Firstly, we can highlight how $19.9 \%$ have a family member with mental illness. Secondly, regarding addictions, tobacco reached the highest levels, above alcohol, $38.7 \%$ of the former by $13.0 \%$ of the latter. Therefore, alcohol consumption among university students was much higher than that existing in their family environment. Finally, two new addictions stand out that are recurrent in our society. On the one hand, addiction to social networks reached $21.6 \%$, a sign of a rapidly changing pattern linked to the use of new technologies; and, on the other hand, addiction to video games, which stood at $16.6 \%$, a growing trend (Laespada and Estévez 2014). We include these results in the table.

Based on the descriptive analysis, a cross-table analysis was performed establishing as a dependent variable the risk of drug consumption differentiating between low and moderate/high. Next, those results that obtained a Pearson's Chi-square with a significance level $p<0.05$ will be presented; that is, those that show a significant relevance and whose association is not determined by chance.

Firstly, concerning the risk of tobacco consumption, an association is observed mainly with the family variables, with the main influence of the fact that there are members of the family unit who are addicted to cocaine and tobacco. On the other hand, if reference is made to the risk of cannabis consumption, an association is observed between the following family variables: addiction to alcohol, tobacco, as well as having a mental illness.

Regarding the risk of cocaine consumption, the variables that show a representative level of the association are the consumption of cannabis, tobacco, and stimulants in the family environment. Concerning the risk of stimulant consumption, this is associated with having a family member with mental illness and with addictions to cocaine and sedatives. It also shows an association with the mother's education. Regarding the risk of consumption of inhalants, the variables with which this variable is associated are having a relative with mental illness and addiction to tobacco, sedatives, and social networks.

The results about the risk of sedatives are striking where a significant level of association is observed with a large number of variables related to social origin: education of the mother, education of the father, work of the father, as well as mental illness of some of his members. Besides, a perfect level of association is shown (0.000) between the risk of sedatives and the addiction to sedatives on the part of some members of the family unit.

In turn, the consumption of hallucinogens is associated with both the work variable of the father, as well as the consumption of the following substances in the family environment: stimulants, sedatives, and cocaine.

Regarding the risk of alcohol, opiates, and other drugs, no relevant levels of significance were observed in terms of chi-square.

Thirdly, we proceeded to use the technique of binary logistic regression through the forward method to evaluate the effect of sociodemographic and family variables on the risk of consumption of the set of addictions. The classifications of the variables used in the binary logistic regression are shown in Table 2. The results of the logistic regressions that presented an adequate model and that showed significant levels of the independent variables are shown in Table 2. 
Table 2. Variables of the equation in logistic regressions according to the type of addiction.

\begin{tabular}{|c|c|c|c|c|c|}
\hline \multicolumn{6}{|c|}{ Tobacco Consumption Risk } \\
\hline & \multirow[b]{2}{*}{ B } & \multirow[b]{2}{*}{ Sig. } & \multirow[b]{2}{*}{$\operatorname{Exp}(B)$} & \multicolumn{2}{|c|}{ 95\% C.I. $\operatorname{Exp}(B)$} \\
\hline & & & & Lower & Higher \\
\hline Family Cocaine Consumer & 2.369 & 0.005 & 10,685 & 2.014 & 56,700 \\
\hline Family Sedatives Consumer & 1.013 & 0.032 & 2.753 & 1.090 & 6.959 \\
\hline Mother's Education & & 0.023 & & & \\
\hline Mother's Education: Medium & 0.832 & 0.012 & 2.299 & 1.199 & 4.409 \\
\hline Mother's Education: Advanced & 0.003 & 0.993 & 1.003 & 0.500 & 2.013 \\
\hline Age & 0.076 & 0.001 & 1.079 & 1.033 & 1.127 \\
\hline \multirow[t]{4}{*}{ Constant } & -3.019 & 0.000 & 0.049 & & \\
\hline & \multicolumn{5}{|c|}{ Alcohol Consumption Risk } \\
\hline & \multirow[b]{2}{*}{ B } & \multirow[b]{2}{*}{ Sig. } & \multirow[b]{2}{*}{$\operatorname{Exp}(B)$} & \multicolumn{2}{|c|}{ 95\% C.I. $\operatorname{Exp}(B)$} \\
\hline & & & & Lower & Higher \\
\hline Family Cocaine Consumer & 2.369 & 0.034 & 5.940 & 1.147 & 30,763 \\
\hline \multirow[t]{4}{*}{ Constant } & 0.003 & 0.000 & 0.517 & & \\
\hline & \multicolumn{5}{|c|}{ Cannabis Consumption Risk } \\
\hline & \multirow[b]{2}{*}{ B } & \multirow[b]{2}{*}{ Sig. } & \multirow[b]{2}{*}{$\operatorname{Exp}(B)$} & \multicolumn{2}{|c|}{$95 \%$ C.I. $\operatorname{Exp}(B)$} \\
\hline & & & & Lower & Higher \\
\hline Family Member with Mental Illness & 0.681 & 0.045 & 1.975 & 1.017 & 3.837 \\
\hline Family Tobacco Consumer & 0.738 & 0.013 & 2.093 & 1.167 & 3.754 \\
\hline Age & -0.084 & 0.026 & 0.919 & 0.854 & 0.990 \\
\hline \multirow[t]{4}{*}{ Constant } & 0.266 & 0.758 & 1.305 & & \\
\hline & \multicolumn{5}{|c|}{ Stimulant Consumption Risk } \\
\hline & \multirow[b]{2}{*}{ B } & \multirow[b]{2}{*}{ Sig. } & \multirow{2}{*}{$\operatorname{Exp}(B)$} & \multicolumn{2}{|c|}{$95 \%$ C.I. $\operatorname{Exp}(B)$} \\
\hline & & & & Lower & Higher \\
\hline Family Cocaine Consumer & 2.549 & 0.013 & 12,793 & 1.720 & 95,126 \\
\hline \multirow[t]{4}{*}{ Constant } & -4.106 & 0.000 & 0.016 & & \\
\hline & \multicolumn{5}{|c|}{ Inhalant Consumption Risk } \\
\hline & \multirow[b]{2}{*}{ B } & \multirow[b]{2}{*}{ Sig. } & & $95 \%$ & $\mathrm{kp}(\mathrm{B})$ \\
\hline & & & $\operatorname{Exp}(B)$ & Lower & Higher \\
\hline Family Tobacco Consumer & 2.482 & 0.029 & 11,963 & 1.292 & 110,729 \\
\hline Family Sedatives Consumer & 2.929 & 0.002 & 18,704 & 2.993 & 116,890 \\
\hline Constant & -5.388 & 0.000 & 0.005 & & \\
\hline & lative Co & imptio & & & \\
\hline & & & & $95 \%$ & $\mathrm{kp}(\mathrm{B})$ \\
\hline & B & Sig. & $\operatorname{Exp}(B)$ & Lower & Higher \\
\hline Family Sedatives Consumer & 2.549 & 0.001 & 5.761 & 2.108 & 15,744 \\
\hline Age & 1.450 & 0.006 & 1.069 & 1.019 & 1.121 \\
\hline Constant & -4.106 & 0.000 & 0.018 & & \\
\hline
\end{tabular}

In the case of logistic regression of tobacco consumption risk, the model was statistically significant $\mathrm{X}^{2}=30,420, p<0.0005$. The model explains $15.0 \%$ (Nagelkerke's $\mathrm{R}^{2}$ ) of the variance of moderately high consumption and correctly classifies $69.4 \%$ of the cases. The Hosmer-Lemeshow test showed that there were no significant differences between the observed and predicted results in the model with a $p=0.107$.

Relatives using cocaine had an $\mathrm{OR}=10.685^{\mathrm{IC} 95 \%[2.014-56.700]}, p=0.005$. In relation to the use of sedatives, it shows an OR $=2.753^{\mathrm{IC} 95 \%[1.090-6.959]}, p=0.032$. In the specific case of the education of the mother (average level), they present an OR $=1.003^{\text {IC } 95 \% ~}[0.500-2.012], p=0.012$. Finally, age expresses an $\mathrm{OR}=1.003^{\mathrm{IC} 95 \%}[0.500-2.012], p=0.012$. Considering these results, we can verify that the risk of moderate/high tobacco consumption increases 10.6 and 2.7 times if the university student lives with relatives addicted to cocaine and sedatives, respectively. The education of the mother, in the case of 
medium level, cause an increase in the risk of consumption almost 2.3 times. Regarding age, for each year added, the moderate/high risk of tobacco consumption increases by 7.9 times.

For the logistic regression of alcohol consumption risk, the model was statistically significant, $\mathrm{X}^{2}=14.078, p<0.0005$. The model explains 7\% (Nagelkerke's $\mathrm{R}^{2}$ ) of the variance of moderately high consumption and correctly classifies $65.7 \%$ of the cases. The Hosmer-Lemeshow test showed that there were no significant differences between the observed and predicted results in the model with a $p=0.911$.

Regarding alcohol addiction, the only predictive variable was cocaine use with an $\mathrm{OR}=5.940^{\mathrm{IC} 95 \%}$ [2.014 to 30.763$], p=0.034$. Therefore, the fact that a family member uses cocaine increase by 5.9 times the chances that the university student uses alcohol.

Concerning logistic regression of cannabis use risk, the model was statistically significant, $\mathrm{X}^{2}=17.063, p<0.0005$. The model explains 9.3\% (Nagelkerke's $\mathrm{R}^{2}$ ) of the variance of moderately high use and correctly classifies $76.9 \%$ of the cases. The Hosmer-Lemeshow test showed that there were no significant differences between the observed and predicted results in the model with a $p=0.235$.

Regarding family members who use tobacco, $\mathrm{OR}=2.093^{\mathrm{IC} 95 \%[1.167-3.754]}, p=0.013$. Mental illness of some members is also a predictive variable showing $\mathrm{OR}=2.093^{\mathrm{IC} 95 \%[1.167-3.754]}, p=0.045$. Finally, age expresses $\mathrm{OR}=0.919^{\mathrm{IC} 95 \%}[0.854-0.990], p=0.026$. Based on these results, we can see that the risk of moderate/high cannabis use increases by 2.1 and 2.0 times if the university student lives with relatives who are addicted to tobacco and one of them suffers from mental illness, respectively. About age, for each year added, there is a one-point reduction in the risk of being a cannabis consumer.

Logistic regression of cannabis use risk in the model was statistically significant $X^{2}=15,201$, $p<0.0005$. The model explains $19.0 \%$ (Nagelkerke's $\mathrm{R}^{2}$ ) of the variance of moderately high use and correctly classifies $96.3 \%$ of the cases. The Hosmer-Lemeshow test showed that there were no significant differences between the observed and predicted results in the model with a $p=0.547$.

The only predictive variable with the consumption of stimulants is related to the consumption of cocaine, presenting an OR $=12.793^{\mathrm{IC} 95 \%}[1.720$ to 95.126$], p=0.013$.

Logistic regression of inhalant use risk in the model was statistically significant $X^{2}=0.000$, $p<0.0005$. The model accounts for $34.3 \%$ (Nagelkerke's $\mathrm{R}^{2}$ ) of the variance of moderately high use and correctly classifies $97.8 \%$ of the cases. The Hosmer-Lemeshow test showed that there were no significant differences between the observed and predicted results in the model with a $p=0.927$.

In the case of inhalants, the two predictor variables are related to the consumption of toxics in the family environment: sedatives and tobacco. Regarding sedatives, it shows an OR $=18.704^{\mathrm{IC} 95 \%[2.993-116.890]}, \quad p=0.002$. Secondly, tobacco consumption shows an $\mathrm{OR}=11.963^{\mathrm{IC} 95 \%}[1.292-110.729], p=0.029$. Sedative and tobacco use reach very high levels as predictors, showing how sedative use in the family setting can increase the likelihood of taking inhalants by almost 19 and 12 points, respectively.

Logistic regression of sedatives use risk in the model was statistically significant $\mathrm{X}^{2}=0.000$, $p<0.0005$. The model explains $14.2 \%$ (Nagelkerke's $\mathrm{R}^{2}$ ) of the variance of moderate-high use and correctly classifies $88.1 \%$ of the cases. The Hosmer-Lemeshow test showed that there were no significant differences between the observed and predicted results in the model with a $p=0.939$.

Finally, in the case of sedatives, there is a repetition of the pattern, and the variable that predicts sedative consumption with the highest level is precisely the consumption of sedatives in the family setting. This variable shows an $\mathrm{OR}=5.761^{\mathrm{IC} 95 \%[2.108-15.744]}, p=0.001$. Therefore, the risk of being addicted to sedatives is increased by 5 times if college students have a family member with this same addiction. Age is also a predictive variable so that as the age of the university student increases by one year, the possibilities of sedative consumption increase by 6.9 points.

\section{Discussion}

The approach to the object of study of university students' consumption from a theoretical and empirical perspective is of great interest to understand this social reality, which has been so little 
studied by official bodies. It was also essential to do so at a time when the COVID-19 pandemic has transformed the world of higher education so much. We considered it essential to carry out a study that reflected the situation in the confinement that occurred as a result of the State of Alarm in Spain, an unusual situation that had never occurred before. This information obtained may be valuable for both the present and the future and may be useful for comparative studies to be carried out in the coming months or years and for preventive protocols.

The consumption of alcohol, tobacco, cannabis, and especially the relevance that sedatives are reaching among the university student population, warns of the need to be more aware of the risks of these drugs. Health education in all educational sections, as well as in the university, is of vital importance to tackle these addictions. The easy access, socialization, commercialization, and consumption of these four drugs cannot imply a relativization of the problem but rather the verification of its scope.

The socialization of alcohol and tobacco is well established among young people in general. In line with other research, the naturalization, acceptance, and social complicity of these drugs, the school, the community, and the family are the most significant contexts for the socialization of young people (Romo-Avilés et al. 2016b; Moore et al. 2010; Böckerman et al. 2017; Sánchez-Sosa et al. 2014) and favor the maintenance of consumption habits throughout this stage of the life cycle. The family and social relativization of alcohol and tobacco have a present and future impact on young university students. Furthermore, cannabis has a high degree of socialization and social acceptance.

This research has shown a high percentage of polydrug use (30.3\%) and alcohol as the most commonly used drug, in line with other studies recently reported in the literature (Liu et al. 2020; Fuentes et al. 2015), in contrast with previous studies that showed cocaine as the most commonly used substance, after cannabis, by college students (Hernández-Serrano et al. 2015). Logistic regressions have shown that there are several predictive variables in drug use. Addiction to cocaine and sedatives and age are the most common variables in the drug mix, although cocaine and sedatives have a greater weight in the probability of predicting the event than age. In the case of sedatives, and in line with other studies (Lukovic et al. 2014), the consumption pattern of $10 \%$ is maintained, even though young people are more aware of the dangers involved in the use of less common substances, such as cocaine, following a pattern evidenced in previous research (World Health Organization (WHO) 2018). This is followed by tobacco addiction in the family setting, the mental illness of some of the family members, and the level of education of the mother.

Sedatives in modern society are acting as another gateway to other drugs, but not from a classic paradigm of consumption in Spain. Sedatives provoke feelings of well-being the addiction to which can approximate the socialization that occurs with alcohol and tobacco. The easy access, usually in the family medicine cabinet, the scarce control over them, and the medicalization of modern societies, especially in Spain, makes a much more far-reaching issue of drug consumption emerge.

The data show that there is a reproduction of consumption in certain drugs, especially sedatives and cocaine, as verified by cross-tabulations and logistic regression. In the specific case of sedatives, there is a family reproduction of consumption of the same drug. Cocaine consumption in the family environment favors the consumption of a significant number of drugs, and similar results are found in other studies (Ruiz et al. 2014; Agudelo Bedoya and Arango 2016; Vega and Alvarado 2019). It seems to act as a glass ceiling over which the entry into the rest of the drugs becomes feasible, possible, or recurrent.

We have also verified in part, as we intended to do, that drug use is not only influenced by family variables - mainly the addictions of other members of the family unit-but also by other socio-demographic variables such as age. Age is a variable that influences the case of cannabis in the opposite way to that of tobacco and sedative use. Thus, the younger college students are, the more likely they are to use cannabis, and the older they become, the more likely they are to use sedatives and tobacco. 
Although the present study was developed during the stage of confinement generated by COVID-19, the results on consumption habits show similarities with other studies, suggesting that access to habitual drugs has been simple, so it is necessary to establish prevention programs to try to reduce consumption.

In terms of the limitations of this research, it should be noted that it was carried out during the declaration of the State of Alarm where access to drugs with a higher level of socialization and acceptance is easier than access to others such as cocaine or stimulants. Despite this contextualization, the results are close to those of other studies carried out on young people, as it has been possible to determine. Future studies should take into account both the component of access to highly socialized drugs (alcohol, tobacco, cannabis) and the use of sedatives whose increase in the student youth population shows a worrying habit to be taken into account in the future.

Another limitation is that the sample could not be larger due to the special circumstances in which the study was conducted. We are referring to the beginning of June, with the State of Alarm active in Spain, all the universities being closed and being in the middle of the examination period. The students, confined to their homes, carried out all academic activities through virtual systems, which meant enormous saturation after many weeks of intensive use of the computer, telematics platforms, and networks. In these circumstances, carrying out another virtual activity, such as the use of an online system to answer a complex questionnaire, greatly depended on their being able to offer their valuable time for it. To this end, the strategy followed was to contact their teachers by asking them in advance for their availability and consent to rigorous and objective participation, which they answered in detail and in a balanced way. In this complex context, the participation of 310 students seems to us valuable and guarantees the quality of data collection. Waiting longer to obtain a larger sample would have prevented us from obtaining the required information at the right time. Despite the complex situation in Spain at that time, the research had all the guarantees of quality and rigor.

\section{Conclusions}

The results of this research show the empirical evidence and the need for educational bodies and university institutions to become aware of the current problems of their students about addictions and to implement awareness, sensitization, and health education programs (Kempf et al. 2017; MacFadden et al. 2020a; Arnaud and Thomasius 2018; Rehbein et al. 2019; Pizon 2019) to reduce or eliminate the consumption of these drugs and correct this maladaptive behavior, which coincides with Goal 3.5, "Strengthen the prevention and treatment of substance abuse, including drug abuse and harmful use of alcohol," within Goal 3, "Ensure a healthy life and promote well-being for all people at all ages," of the Sustainable Development Goals (The United Nations 2019; MacFadden et al. 2020b).

Since family drug use predicts consumption by university students, the measures to be implemented should address these aspects. Therefore, individual perceptions of drug use should be strengthened, and university students should be given the tools to make family influence more limited and less conditioned by subsequent consumption. Furthermore, and as we have insisted before, exceptional circumstances—such as the current pandemic-could aggravate this problem. The protocols to be established must also be flexible enough to respond to each particular moment. The preventive approach is fundamental; it is always better to avoid a problem arising than to try to correct it when it already exists.

Author Contributions: Conceptualization, C.L.-P., J.Á.M.-L., J.G.-G.; methodology, C.L.-P., J.Á.M.-L., J.G.-G.; validation, C.L.-P., J.Á.M.-L., J.G.-G.; formal analysis, C.L.-P., J.Á.M.-L., J.G.-G.; investigation, C.L.-P., J.Á.M.-L., J.G.-G.; data curation, C.L.-P., J.Á.M.-L., J.G.-G.; writing-original draft preparation, C.L.-P., J.Á.M.-L., J.G.-G.; writing—review and editing, C.L.-P., J.Á.M.-L., J.G.-G.; supervision, C.L.-P., J.Á.M.-L., J.G.-G.; project administration, C.L.-P., J.Á.M.-L., J.G.-G. All authors have read and agreed to the published version of the manuscript.

Funding: This research received no external funding. 
Conflicts of Interest: The authors declare no conflict of interest.

\section{Appendix A}

Table A1. Variables used in binary logistic regression.

\begin{tabular}{|c|c|}
\hline 1. Gender & 11. Fam. Cocaine \\
\hline Ref. Woman & Ref. No \\
\hline (1) Man & (1) Yes \\
\hline 2. Age (Continue) & 12. Fam. Stimulants \\
\hline 3. Knowledge Branch & Ref. No \\
\hline Ref. Arts and Humanities & (1) Yes \\
\hline Science & 13. Fam. Inhalants \\
\hline Health Sciences & Ref. No \\
\hline Social and Legal Sciences & (1) Yes \\
\hline Engineering and Architecture & 14. Fam. Sedatives \\
\hline 4. Mother's Education & Ref. No \\
\hline Ref. Basic & (1) Yes \\
\hline (1) Medium & 15. Fam. Hallucinogens \\
\hline (2) Advanced & Ref. No \\
\hline 5. Father's Education & (1) Yes \\
\hline Ref. Basic & 16. Fam. Opiates \\
\hline (1) Medium & Ref. No \\
\hline (2) Advanced & (1) Yes \\
\hline 6. Mother's Profession & 17. Fam. Other Drugs \\
\hline Ref. Employed & Ref. No \\
\hline (1) Unemployed/Inactive & (1) Yes \\
\hline 7. Father's Profession & Ref. No \\
\hline Ref. Employed & 18. Fam. Alcohol \\
\hline (1) Unemployed/Inactive & Ref. No \\
\hline 8. Fam. Tobacco & (1) Yes \\
\hline Ref. No & 19. Fam. Alcohol \\
\hline (1) Yes & Ref. No \\
\hline 9. Fam. Alcohol & (1) Yes \\
\hline Ref. No & 20. Fam. Mental Disease \\
\hline (1) Yes & Ref. No \\
\hline 10. Fam. Cannabis & (1) Yes \\
\hline \multicolumn{2}{|l|}{ Ref. No } \\
\hline (1) Yes & \\
\hline
\end{tabular}

The analyses were adjusted for all features described in Table A1. 


\section{References}

Agudelo Bedoya, Maria Eugenia, and Piedad Estrada Arango. 2016. The consumption of psychoactive substances and forms of family organization and dynamics. Trabajo Social 18: 145-56.

American Psychiatric Association. 2013. Diagnostic and Statistical Manual of Mental Disorders, 5th ed. (DSM-5). New York: American Psychiatric Publishing. Available online: http://www.psychiatry.org/dsm5 (accessed on 20 September 2020).

Anser, Muhammad Khalid, Zahid Yousaf, Muhammad Azhar Khan, Abdelmohsen A Nassani, Saad M Alotaibi, Muhammad Moinuddin Qazi Abro, Xuan Vinh Vo, and Khalid Zaman. 2020. Does communicable diseases (including COVID-19) may increase global poverty risk? A cloud on the horizon. Environmental Research 187: 109668. [CrossRef] [PubMed]

Armitage, Richard, and Laura B Nellums. 2020. The COVID-19 response must be disability inclusive. The Lancet Public Health 5: e257. [CrossRef]

Arnaud, Nicolas, and Rainer Thomasius. 2018. Prävention von stoffgebundenen Suchtstörungen. Zeitschrift für Kinder-und Jugendpsychiatrie und Psychotherapie. [CrossRef]

Bartsch, Lauren A., Keith A King, Rebecca Vidourek, and Ashley L Merianos. 2017. Self-esteem and alcohol use among youths. Journal of Child and Adolescent Substance Abuse 26: 414-24. [CrossRef]

Becoña, Elisardo, and Maite Cortés. 2011. Manual de Adicciones para Psicólogos Especialistas en Psicología Clínica en Formación. Valencia: Socidrogalcohol.

Belzunegui-Eraso, Angel, Inma Pastor-Gosálbez, Laia Raigal-Aran, Francesc Valls-Fonayet, Sonia Fernández-Aliseda, and Teresa Torres-Coronas. 2020. Substance use among Spanish adolescents: The information paradox. International Journal of Environmental Research and Public Health 17: 627. [CrossRef] [PubMed]

Berlanga-Silvente, Vanesa, and Ruth Vila-Baños. 2014. Cómo obtener un modelo de regresión logística binaria con SPSS. Revista d'Innovació i Recerca en Educació 7: 105-18.

Blest-Hopley, Grace, Vincent Giampietro, and Sagnik Bhattacharyya. 2020. A systematic review of human neuroimaging evidence of memory-related functional alterations associated with cannabis use complemented with preclinical and human evidence of memory performance alterations. Brain Sciences 10: 102. [CrossRef]

Bloem, Oscar, Erik Bulten, and Robbert-Jan Verkes. 2019. Changes in subjective wellbeing of prisoners on remand. International Journal of Prisoner Health 15: 181-91. [CrossRef]

Böckerman, Petri, Ari Hyytinen, and Terhi Maczulskij. 2017. Alcohol consumption and long-term labor market outcomes. Health Economics 26: 275-91. [CrossRef]

BOE. 2005. BOE Ley 28/2005, de 26 de diciembre, de medidas sanitarias frente al tabaquismo y reguladora de la venta, el suministro, el consumo y la publicidad de los productos del tabaco. Available online: https://www.boe.es/buscar/doc.php?id=BOE-A-2005--21261 (accessed on 20 September 2020).

Bosque-Prous, Marina, Mirte A. Kuipers, Albert Espelt, Matthias Richter, Arja Rimpelä, Julian Perelman, Bruno Federico, Maria Teresa Brugal, Vicent Lorant, and Anton E. Kunst. 2017. Adolescent alcohol use and parental and adolescent socioeconomic position in six European cities. BMC Public Health 17: 646. [CrossRef]

Boyle, Coleen A., Michael H. Fox, Susan M. Havercamp, and Jennifer Zubler. 2020. The public health response to the COVID-19 pandemic for people with disabilities. Disability and Health Journal 13: 100943. [CrossRef]

Brown, Eric E., Sanjeev Kumar, Tarek K. Rajji, Bruce G. Pollock, and Benoit H. Mulsant. 2020. Anticipating and mitigating the impact of COVID-19 pandemic on alzheimer's disease and related dementias. The American Journal of Geriatric Psychiatry, 32331845. [CrossRef]

Brunetti, Pietro, Simona Pichini, Roberta Pacifici, Francesco Paolo Busardò, and Alessandro del Rio. 2020. Herbal preparations of medical cannabis: A vademecum for prescribing doctors. Medicina 56: 237. [CrossRef] [PubMed]

Brunner, Franziska, Insa Neumann, Dahlnym Yoon, Martin Rettenberger, Elisabeth Stück, and Peer Briken. 2019. Determinants of dropout from correctional offender treatment. Frontiers in Psychiatry 10: 142. [CrossRef]

Caamaño-Isorna, Francisco, Montserrat Corral, Maria Parada, and Fernando Cadaveira. 2008. Factors associated with risky consumption and heavy episodic drinking among Spanish university students. Journal of Studies on Alcohol and Drugs 69: 308-12. [CrossRef] [PubMed] 
Ruiz, Hector, Aleida Herrera Batista, Ayní Martínez, and Mayda Supervielle. 2014. Comportamiento adictivo de la familia como factor de riesgo de consumo de drogas en jóvenes y adolescentes adictos. Revista Cubana de Investigaciones Biomédicas 33: 402-9.

Cruces-Montes, Serafin, Ana Merchán-Clavellino, Antonio Romero-Moreno, and Alberto Paramio. 2020. Perception of the attributes of sherry wine and its consumption in young people in the South of Spain. Foods 9: 417. [CrossRef]

Di Gennaro, Francesco, Damiano Pizzol, Claudia Marotta, Mario Antunes, Vincenzo Racalbuto, Nicola Veronese, and Lee Smith. 2020. Coronavirus diseases (COVID-19) current status and future perspectives: A narrative review. International Journal of Environmental Research and Public Health 17: 2690. [CrossRef]

Díaz Geada, Ainara, Alicia Busto Miramontes, and Francisco Caamaño. 2018. Consumo de alcohol, tabaco y cannabis en adolescentes de una población multicultural. Adicciones 30: 264-70. [CrossRef] [PubMed]

Douglas, Margaret, Srinivasa Vittal Katikireddi, Martin Taulbut, Martin McKee, and Gerry McCartney. 2020. Mitigating the wider health effects of covid-19 pandemic response. BMJ 369: m1557. [CrossRef]

Doyle, Michael, Anthony Shakeshaft, Jill Guthrie, Mieke Snijder, and Tony Butler. 2019. A systematic review of evaluations of prison-based alcohol and other drugs use behavioral treatment for men. Australian and New Zealand Journal of Public Health 43: 120-30. [CrossRef]

Duan, Li, and Gang Zhu. 2020. Psychological interventions for people affected by the COVID-19 epidemic. The Lancet Psychiatry 7: 300-2. [CrossRef]

Egan, Sarah, Tracey Wade, and Roz Shafran. 2011. Perfectionism as a transdiagnostic process: A clinical review. Transdiagn. Transtheor. Approaches 31: 203-12. [CrossRef]

European Monitoring Center for Drugs and Drug Addiction (EMCDDA). 2018. Medical Use of Cannabis and Cannabinoids: Questions and Answers for Policy Making. Available online: http://www.emcdda.europa.eu/ system/files/publications/ (accessed on 21 September 2020).

Eurostat. 2020. Smoking of Tobacco Products by Sex, Age and Country of Birth. Available online: https: //appsso.eurostat.ec.europa.eu/nui/show.do (accessed on 21 September 2020).

Filbey, Francesca. 2019. The Neuroscience of Addiction. Cambridge: Cambridge University Press.

Fuentes, M., A. Alarcón, F. García, and E. Gracia. 2015. Consumo de alcohol, tabaco, cannabis y otras drogas en la adolescencia: Efectos de la familia y peligro del barrio. Anales de Psicología 31: 1000-7. [CrossRef]

Gage, Suzanne, and Harry R. Sumnall. 2018. Rat park: How rat paradise changes the narrative of addiction. Addiction 114: 917-22. [CrossRef] [PubMed]

Garnier-Crussard, Antoine, Emmanuel Forestier, Thomas Gilbert, and Pierre Krolak-Salmon. 2020. Novel Coronavirus (COVID-19) Epidemic: What Are the Risks for Older Patients? Journal of the American Geriatrics Society 68: 939-40. [CrossRef]

Gerra, G., E. Benedetti, G. Resce, R. Potente, A. Cutilli, and S. Molinaro. 2020. Socioeconomic status, parental education, school connectedness and individual socio-cultural resources in vulnerability for drug use among students. International Journal of Environmental. Research and Public Health 17: 1306. [CrossRef] [PubMed]

Gervilla, Elena, and Alfonso Palmer Pol. 2009. Predicción del consumo de cocaína en adolescentes mediante árboles de decisión. Revista de Investigación en Educación 6: 7-13.

Gómez-Salgado, Juan, Montserrat Andrés-Villas, Sara Domínguez-Salas, Diego Díaz-Milanés, and Carlos Ruiz-Frutos. 2020. Related Health Factors of Psychological Distress During the COVID-19 Pandemic in Spain. International Journal of Environmental Research and Public Health 17: 3947.

Gonzálvez, Maria, Jose Espada, Iván Fernández-Martínez, Mireia Orgilés, and Steve Sussman. 2020. Group self-identification, drug use and psychosocial correlates among Spanish adolescents. Revista de Psicología Clínica con Niños y Adolescentes 7: 59-64. [CrossRef]

Greaves, Lorraine, and Natalie Hemsing. 2020. Sex and gender interactions on the use and impact of recreational cannabis. International Journal of Environmental Research and Public Health 17: 509. [CrossRef]

Hernández-Serrano, Olga, Silvia Font-Mayolas, and Maria Eugenia Gras. 2015. Policonsumo de drogas y su relación con el contexto familiar y social en jóvenes universitarios. Adicciones 27: 205-13. [CrossRef]

Holmes, Emily, Rory C. OConnor ', V. Hugh Perry, Irene Tracey, Simon Wessely, Louise Arseneault, Clive Ballard, Helen Christensen, Roxane Cohen Silver, Ian Everall, and et al. 2020. Multidisciplinary research priorities for the COVID-19 pandemic: A call for action for mental health science. The Lancet Psychiatry 7: 547-60. [CrossRef] 
INE. 2020. Encuesta de Población Activa. Available online: https://www.ine.es/dyngs/INEbase/es (accessed on 20 September 2020).

Iriart, Celia, and Emerson Elias Merhy. 2017. Inter-capitalistic disputes, biomedicalization and hegemonic medical model. Interface 21: 1005-16. [CrossRef]

Jander, Astrid, Liesbeth Mercken, Rik Crutzen, and Hein de Vries. 2013. Determinants of binge drinking in a permissive environment: Focus group interviews with Dutch adolescents and parents. BMC Public Health 13: 882. [CrossRef]

Kempf, Cédric, Pierre-Michel Llorca, Frank Pizon, Georges Brousse, and Valentin Flaudias. 2017. What's new in addiction prevention in young people: A literature review of the last years of research. Frontiers in Psychology 8: 1131. [CrossRef] [PubMed]

Kim, Hyoun S., David C. Hodgins, Benjamin Kim, and T. Cameron Wild. 2020. Transdiagnostic or disorder specific? Indicators of substance and behavioral addictions nominated by people with lived experience. Journal of Clinical Medicine 9: 334. [CrossRef] [PubMed]

Laespada, Maria Teresa, and Ana Estévez. 2014. ¿Existen las adicciones sin sustancias?.¿ Existen las adicciones sin sustancias? Bilbao: Deusto Digital.

Lancet. 2020. Redefining vulnerability in the era of COVID-19. The Lancet 395: 1089. [CrossRef]

Laporte, Joan-Ramon, and David Healy. 2020. In the MidstI of the SARS-CoV-2 Pandemia. Caution Is needed with Commonly Used Drugs That Increase the Risk of Pneumonia. Available online: https: //rxisk.org/medications-compromising-covid-infections/ (accessed on 20 September 2020).

Legleye, Stéphane, François Beck, Myriam Khlat, Patrick Peretti-Watel, and Nearkasen Chau. 2012. The influence of socioeconomic status on cannabis use among French adolescents. Jornal of Adolescent Health 50: 395-402. [CrossRef]

Liu, Zhaorui, Bing Han, Rongmeng Jiang, Yueqin Huang, Chao Ma, Jing Wen, Tingting Zhang, Ying Wang, Hongguang Chen, and Yongchun Ma. 2020. Mental Health Status of Doctors and Nurses during COVID-19 Epidemic in China. Available online: https://ssrn.com/abstract=3551329 (accessed on 21 September 2020).

Lukovic, Jasminka Adzic, Vladimir Miletic, Tatjana Pekmezovic, Goran Trajkovic, Nevena Ratkovic, Danijela Aleksic, and Anita Grgurevic. 2014. Self-medication practices and risk factors for self-medication among medical students in Belgrade, Serbia. PLoS ONE 9: e114644. [CrossRef]

Luquiens, Amandine, Bruno Falissard, and Henri-Jean Aubin. 2016. Students worry about the impact of alcohol on quality of life: Roles of frequency of binge drinking and drinker self-concept. Drug and Alcohol Dependence 167: 42-48. [CrossRef]

MacFadden, Isotta, Eloy López-Meneses, José Luis Sarasola, and José Gómez-Galán. 2020a. La Marginalidad Avanzada para el Desarrollo Sostenible de la Ciudadanía Global. Barcelona: Octaedro.

MacFadden, Isotta, Eloy López-Meneses, José Luis Sarasola, and José Gómez-Galán. 2020b. Reflections on Investigating the Complexity of Social Cohesion in the Era of Globalization. Badajoz: Eurytion Press.

Maremmani, Angelo G., Luca Cerniglia, S. Cimino, Silvia Bacciardi, L. Rovai, Fabio Rugani, Enrico Massimetti, Denise Gazzarrini, Alessandro Pallucchini, Pier Paolo Pani, and et al. 2015. Towards a specific psychopathology of heroin addiction. Comparison between Heroin Use Disorder and Major Depression patients. Heroin Addiction and Related Clinical Problems 17: 9-16.

Marsden, John, Shane Darke, Wayne Hall, Matt Hickman, John Holmes, Keith Humphreys, Joanne Neale, Jalie Tucker, and Robert West. 2020. Mitigating and learning from the impact of COVID-19 infection on addictive disorders. Addiction 115: 1007-10. [CrossRef]

Martínez-Gayo, Gema, and José Ángel Martínez-López. 2020. Salud y privación farmacéutica: Una devaluación de la ciudadanía social. Gerencias y Políticas de Salud. preprint edition.

Martínez-López, José Ángel, and Gema Martínez-Gayo. 2019. Implicaciones del aumento del copago farmacéutico en España: Una nueva privación material. Convergencia, 26. [CrossRef]

Melero, Silvia, Alexandra Morales, José Pedro Espada, I. Fernández-Martínez, and M. Orgilés. 2020. How Does Perfectionism Influence the Development of Psychological Strengths and Difculties in Children? International Journal of Environmental Research of Public Health 17: 4081. [CrossRef]

Mesa, Cristina, Oscar H. Franco, Carlos Gómez Restrepo, and Thomas Abel. 2020. COVID-19: The forgotten priorities of the pandemic. Maturitas 136: 38-41. [CrossRef] [PubMed]

Ministerio de Ciencia, and Innovación y Universidades. 2019. Datos y Cifras. Available online: https: //www.ciencia.gob.es/stfls/MICINN/Universidades/Ficheros/Estadisticas (accessed on 21 September 2020). 
Moore, Graham F., Heather Rothwell, and Jeremy Segrott. 2010. An exploratory study of the relationship between parental attitudes and behaviour and young people's consumption of alcohol. Substance Abuse Treatment, Prevention, and Policy 5: 6. [CrossRef] [PubMed]

Morley, John E., and B. Vellas. 2020. COVID-19 and older adult. Journal of Nutrition, Health and Aging 24: 364-65. [CrossRef] [PubMed]

Mota, Nayara, Rosa Alvarez-Gil, Montserrat Corral, Socorro Rodríguez-Holguín, Maria Parada, Alberto Crego, Francisco Caamaño-Isorna, and Fernando Cadaveira. 2010. Risky alcohol use and heavy episodic drinking among Spanish University students: A two-year follow-up. Gaceta Sanitaria 24: 372-77. [CrossRef]

Moure-Rodríguez, Lucia, María Piñeiro, Montserrat Corral Varela, Socorro Rodríguez-Holguín, Fernado Cadaveira, and Francisco Caamaño-Isorna. 2016. Identifying predictors and prevalence of alcohol consumption among university students: Nine years of follow-up. PLoS ONE 11: e0165514. [CrossRef]

Observatorio Español de las Drogas y las Adicciones. 2019. Encuesta sobre Uso de Drogas en Enseñanzas Secundarias en España (ESTUDES) 1994-2018; Madrid: Ministerio de Sanidad, Consumo y Bienestar Social.

Observatorio Español sobre Drogas. 2019. Informe 2019. Alcohol, Tabaco y Drogas Ilegales en España; Madrid: Ministerio de Sanidad, Consumo y Bienestar Social.

Observatorio Europeo de Drogas y Toxicomanías. 2020. Visión General. Available online: https://europa.eu/ european-union/about-eu/agencies/emcdda_es (accessed on 19 September 2020).

OME-OSALDE. 2020. Guía 3. Apoyo Frente a las Adicciones Durante esta Epidemia de Coronavirus. Available online: https://osalde.org/guias-de-apoyo-en-esta-epidemia-de-coronavirus-2/ (accessed on 20 September 2020).

Panchal, Nirmita, Rabah Kamal, Kendal Orgera, Cynthia Cox, Rachel Garfield, Liz Hamel, and Priya Chidambaram. 2020. The Implications of COVID-19 for Mental Health and Substance Use. Kaiser Family Foundation. Available online: https://www.kff.org/coronavirus-covid-19/issue-brief/the-implications-of-covid-19-formental-health-and-substance-use/ (accessed on 19 September 2020).

Parolin, Micol, Patrizia Cristofalo, Silvia Bracciardi, Silvia Cimino, and Luca Cerniglia. 2017. Drug addiction and emotional dysregulation in young adults. Heroin Addiction and Related Clinical Problems 19: 37-48.

Pedersen, Willy, and Tilmann von Soest. 2013. Socialization to binge drinking: A population based, longitudinal study with emphasis on parental influences. Drug and Alcohol Dependence 133: 587-92. [CrossRef] [PubMed]

Pedrero-Perez, Eduardo J., Gloria Rojo-Mota, and Carmen Puerta-García. 2008. Estilos de afrontamiento del estrés y adicción. Revista Española de Drogodependencias 33: 256-70.

Perelman, Julian, Teresa Leão, and Anton E. Kunst. 2019. Smoking and school absenteeism among 15-to 16-year-old adolescents: A cross-section analysis on 36 European countries. European Journal of Public 29: 778-84. [CrossRef]

Pfefferbaum, Betty, and Carol S. North. 2020. Mental health and the Covid-19 pandemic. New England Journal of Medicine. [CrossRef]

Pizon, Frank. 2019. Health Education and Prevention. Hoboken: John Wiley \& Sons.

Põld, Mariliis, and Kersti Pärna. 2020. Nicotine dependence and factors related to smoking cessation among physicians in Estonia. International Journal of Environmental Resesarch and Public Health 17: 3217. [CrossRef]

Puiguriguer-Ferrando, Jordi, Christopher Yates-Bailo, Elena Gervilla-García, Juan Ortega-Pérez, Elena Alfaro García-Belenguer, and Rafael Jiménez-López. 2019. Evolución temporal de las intoxicaciones medicamentosas. Emergencias 31: 107-10. [PubMed]

Quaglieri, Alessandro, Emanuela Mari, Maddalena Boccia, Laura Piccardi, Cecilia Guariglia, and Anna Maria Giannini. 2020. Brain Network Underlying Executive Functions in Gambling and Alcohol Use Disorders: An Activation Likelihood Estimation Meta-Analysis of fMRI Studies. Brain Sciences 10: 353. [CrossRef] [PubMed]

Rajkumar, Ravi Philip. 2020. COVID-19 and mental health: A review of the existing literature. Asian Journal of Psychiatry 52: 102066. [CrossRef]

Rehbein, Florian, Jan Philip Weber, Marie Christine Bergmann, Hans-Jürgen Rumpf, and Dirk Baier. 2019. Reichweite von Suchtprävention aus der Perspektive jugendlicher Endadressaten. Sucht 65: 1-12. [CrossRef]

Rojas-Jara, C. 2020. Cuarentena, aislamiento forzado y uso de drogas. Panamerican Journal of Neuropsychology 14: 24-28.

Rolando, Sara, Franca Beccaria, Enrico Petrilli, and Franco Prina. 2014. Adults' views of young people's drinking in Italy: An explorative qualitative research. Drugs: Education, Prevention and Policy 21: 388-97. [CrossRef] 
Romo-Avilés, Nuria, Jorge Marcos-Marcos, Alfonso Marquina-Márquez, and Eugenia Gil-García. 2016a. Intensive alcohol consumption by adolescents in Southern Spain: The importance of friendship. International Journal of Drug Policy 31: 138-46. [CrossRef]

Romo-Avilés, Nuria, Jorge Marcos-Marcos, Alfonso Marquina-Márquez, Alicia Tarragona-Camacho, and Eugenia Gil-García. 2016b. "I like to be di_erent from how I normally am": Heavy alcohol consumption among female Spanish adolescents and the unsettling of traditional gender norms. International Journal of Drug Policy 25: 262-72.

San Martín, Álvaro. 2020. Aproximación al abuso de sustancias en el lugar de trabajo en los Estados Unidos y en España: Comparación de ambos sistemas. Lan Harremanak-Revista de Relaciones Laborales 43: 1-13.

Sánchez-Sosa, Juan Carlos, María Elena Villarreal-González, María Elena Ávila Guerrero, Alejandro Vera Jiménez, and Gonzalo Musitu. 2014. Contextos de socialización y consumo de drogas ilegales en adolescentes escolarizados. Psychosocial Intervention 23: 69-78. [CrossRef]

Santos, Cátia Fernades. 2020. Reflections about the impact of the SARS-COV-2/COVID-19 pandemic on mental health. Brazilian Journal of Psychiatry 42: 329-29. [CrossRef]

Schiariti, Verónica. 2020. The human rights of children with disabilities during health emergencies: The challenge of COVID-19. Developmental Medicine E Child Neurology 62: 661-61.

Song, Eun-Young, Andrew P. Smiler, Kimberly G. Wagoner, and Mark Wolfson. 2012. Everyone says it's ok: Adolescents' perceptions of peer, parent, and community alcohol norms, alcohol consumption, and alcohol-related consequences. Substance Use \& Misuse 47: 86-98.

Tafà, Mimma, Silvia Cimino, Giulia Ballarotto, Fabrizia Bracaglia, Chiara Bottone, and Luca Cerniglia. 2017. Female adolescents with eating disorders, parental psychopathological risk and family functioning. Journal of Child and Family Studies 26: 28-39. [CrossRef]

Taylor, Steven. 2019. The Psychology of Pandemics: Preparing for the Next Global Outbreak of Infectious Disease. Cambridge: Cambridge Scholars Publishing.

The United Nations. 2019. Objetivos de Desarrollo Sostenible. Available online: https://www.un.org/ sustainabledevelopment/es/health/ (accessed on 20 September 2020).

Thelwall, Mike, and Jonathan M. Levitt. 2020. Retweeting Covid-19 disability issues: Risks, support and outrage. El Profesional de la Información 29: e290216. [CrossRef]

Thylstrup, B., T. Clausen, and M. Hesse. 2015. Enfermedad cardiovascular en personas con trastornos por consumo de drogas. Revista Internacional de Salud Pública 60: 659-68.

United Nations. 1961. Single Conference on Narcotic Drugs. Available online: https://www.unodc.org/pdf/ convention_1961_en.pdf (accessed on 18 September 2020).

Van der Steur, Sanne J., Albert Batalla, and Matthijs G. Bossong. 2020. Factors moderating the association between cannabis use and psychosis risk: A systematic review. Brain Sciences 10: 97. [CrossRef]

Vardavas, Constantine I., and Katerina Nikitara. 2020. COVID-19 and smoking: A systematic review of the evidence. Tobacco Induced Diseases. [CrossRef]

Vargas-Martínez, Ana Magdalena, Marta Trapero-Bertran, Toni Mora, and Marta Lima-Serrano. 2020. Social, economic and family factors associated with binge drinking in Spanish adolescents. BMC Public Health 20: 519. [CrossRef]

Vega, Juan Luis, and Teresa Alvarado. 2019. Psychosocial factors involved in the consumption of psychotropic substances in adolescents attending a family medicine unit. Atención Familiar 26: 63-67.

Vicario-Merino, Ángel, and Noemi Muñoz-Agustín. 2020. Analysis of the stress, anxiety and healthy habits in the Spanish Covid-19 confinement. Health Science Journal 14: 707.

Villalbí, Joan, Josep Suelves, Xavier García-Continente, Esteve Saltó, Carles Ariza, and Carmen Cabezas. 2012. Cambios en la prevalencia del tabaquismo en los adolescentes en España. Atención Primaria 44: $36-42$. [CrossRef]

Volkow, Nora D. 2020. Collision of the COVID-19 and addiction epidemics. Annals of Internal Medicine, M20-1212. [CrossRef]

WHO. 2010. ASSIST. Available online: https://www.who.int/substance_abuse/activities/ (accessed on 20 September 2020).

Winhusen, Theresa M., Jeff Theobald, and Daniel F. Lewis. 2019. Substance use outcomes in cocaine-dependent tobacco smokers: A mediation analysis exploring the role of sleep disturbance, craving, anxiety, and depression. Journal of Substance Abuse Treatment 96: 53-57. [CrossRef] 
World Health Organization (WHO). 2018. ICD-10: International Statistical Classification of Diseases and Related Health Problems: Eleventh Revision. Geneva: World Health Organization.

World Health Organization. 2016. The Health and Social Effects of Non-Medical Cannabis Use. Geneva: World Health Organization.

Xie, Xinyan, Qi Xue, Yu Zhou, Kaiheng Zhu, Qi Liu, Jiajia Zhang, and Ranran Song. 2020. Mental health status among children in home confinement during the coronavirus disease 2019 outbreak in Hubei Province, China. JAMA Pediatrics, e201619. [CrossRef]

Yao, Hao, Jian-Hua Chen, and Yi-Feng Xu. 2020. Patients with mental health disorders in the COVID-19 epidemic. The Lancet Psychiatry 7: e21. [CrossRef]

Publisher's Note: MDPI stays neutral with regard to jurisdictional claims in published maps and institutional affiliations.

(C) 2020 by the authors. Licensee MDPI, Basel, Switzerland. This article is an open access article distributed under the terms and conditions of the Creative Commons Attribution (CC BY) license (http://creativecommons.org/licenses/by/4.0/). 